\title{
Mössbauer spectroscopy of samples from the 2010 Fimmvörðuháls/Eyjafjallajökull eruption
}

\author{
H. P. Gunnlaugsson • Á. Höskuldsson • \\ S. Steinthorsson · N. Óskarsson • M. B. Madsen • \\ P. Nørnberg • J. Merrison • G. Larsen
}

Published online: 26 November 2013

(C) Springer Science+Business Media Dordrecht 2013

\begin{abstract}
Mössbauer spectra of samples from the 2010 Fimmvörouháls/Eyjafjallajökull eruption are presented with determinations of the $\mathrm{Fe}^{3+} / \mathrm{Fe}_{\mathrm{Tot}}$ ratios. Mössbauer spectra of time series of samples from the Eyjafjallajökull eruption show a change in the characteristics of the erupted material mid-way in the eruption, suggesting changing access of water to the eruption.
\end{abstract}

Keywords Mössbauer spectroscopy • Volcanic ash • Eyjafjallajökull eruption 2010 • Fimmvörðuháls eruption 2010

\section{Introduction}

The 2010 Eyjafjallajökull summit eruption (Iceland) produced large amounts of fine ash, disturbing air traffic across the North-Atlantic and within much of Europe (see e.g. [1]). The eruption phase started with a flank eruption on the 20th of March 2010 at Fimmvörðuháls, a glacier-free area between Eyjafjallajökull and Mýrdalsjökull. The expelled magma was olivine- and plagioclase-bearing mildly-alkaline basalt that

Proceedings of the 32nd International Conference on the Applications of the Mössbauer Effect (ICAME 2013) held in Opatija, Croatia, 1-6 September 2013.

H. P. Gunnlaugsson $(\varangle) \cdot$ J. Merrison

Department of Physics and Astronomy, Aarhus University, 8000 Aarhus C, Denmark

e-mail: hpg@phys.au.dk

Á. Höskuldsson · S. Steinthorsson · N. Óskarsson · G. Larsen

NORDVULK, Institute of Earth Sciences, Askja, University of Iceland, 101 Reykjavik, Iceland

M. B. Madsen

Niels Bohr Institute, University of Copenhagen, 2100 Copenhagen $\varnothing$, Denmark

P. Nørnberg

Department of Earth Sciences, Aarhus University, 8000 Aarhus C, Denmark 
Table 1 Eruption phases of the Fimmvörðuháls/Eyjafjallajökull eruptions 2010

\begin{tabular}{lll}
\hline Eruption phase & Dates & Description \\
\hline 0 & $20 / 3 / 2010-12 / 4 / 2010$ & Flank eruption at Fimmvörðuháls \\
1 & $14 / 4 / 2010-17 / 4 / 2010$ & First explosive phase at Eyjafjallajökull \\
2 & $18 / 4 / 2010-3 / 5 / 2010$ & Declining activity, lava flow at Eyjafjallajökull, \\
& & coarse grained tephra erupted \\
3 & $4 / 5 / 2010-17 / 5 / 2010$ & Second explosive phase, new magma seems \\
& & to have entered the system at 2-3/5/2010 \\
4 & $18 / 5 / 2010-22 / 5 / 2010$ & Declining explosive activity at Eyjafjallajökull \\
\hline
\end{tabular}

This sub-division is given by papers in [1] and the Fimmvörðuháls eruption is added as phase 0

exhibits uniform and rather primitive whole-rock composition $\left(\mathrm{SiO}_{2} \sim 46-47\right.$ wt. \%) [2]. This eruption phase ended on 12th of April 2010.

On the 14th of April, 2010 a summit eruption started at the Eyjafjallajökull stratovolcano of benmoreitic to trachytic composition $\left(\mathrm{SiO}_{2} \sim 56\right.$ wt. \%) [3]. The summit eruption has been subdivided into four phases (Table 1).

Geochemical studies of the erupted material from the Eyjafjallajökull eruption $[3,4]$ shows mixing and mingling of two components, an evolved FeTi-basalt, derived from material similar in composition as that erupted at Fimmvörðuháls and remobilized silicic melt with composition similar to that produced by the 1821-1823 AD Eyjafjallajökull summit eruption $\left(\mathrm{SiO}_{2} \sim 69 \%\right.$ [5]). Both the end-membercompositions and their mixing ratios changed with time, and mingling of the two was rapid and incomplete such that the two components are often preserved on a micrometre scale in samples obtained from the eruptions.

In this contribution we present Mössbauer spectra of samples from the eruptions and determine their $\mathrm{Fe}^{3+} / \mathrm{Fe}_{\mathrm{Tot}}$ ratios.

\section{Samples and experimental}

Two tephra samples from the Fimmvörouháls eruption are used in this study, labelled according to the collection date 22/3 2010 (coll. P. Kristjánsson) and 24/3 2010 (coll. Á. Höskuldsson). These samples are compared to a rock sample from the lava flow at Fimmvörðuháls (coll. 24/3 2010, Á. Höskuldsson).

Ten tephra samples from the Eyjafjallajökull eruption were used and also labelled after eruption date in 2010; 13/4, 14/4, 22/4 (a), 3/5, 7/5, 14/5, 20/5 (coll. Á. Höskuldsson and G. Larsen), 17/4 (coll. J. Merrison) and 22/4 (b) and 27/4 are samples EJ-3 and EJ-4 from [3]. All samples except the sample from 22/4 (a) exhibit a broad grain-size distribution and are brownish in appearance. The 22/4 (a) sample is darker coarse-grained material.

Samples of a lava bomb from the Eyjafjallajökull eruption were also studied. The sample was collected after the eruption, and is thought to be from the latest stages of the eruption (Á. Höskuldsson, private communication, 2011).

A sample from the 1821-1823 AD Eyjafjallajökull eruption was also measured for comparison.

The Mössbauer spectra presented here were measured at room temperature in transmission mode using a conventional constant acceleration drive system and $5-25 \mathrm{mCi}{ }^{57} \mathrm{Co}: \mathrm{Rh}$ sources. Velocities and isomer shifts are given relative to the centre of the spectrum of $\alpha$-Fe at room temperature. 
Fig. 1 Mössbauer spectra of tephra samples from Fimmvörðuháls. Solid lines show the fitting components indicated with a bar diagram at the top and their sum (black line)

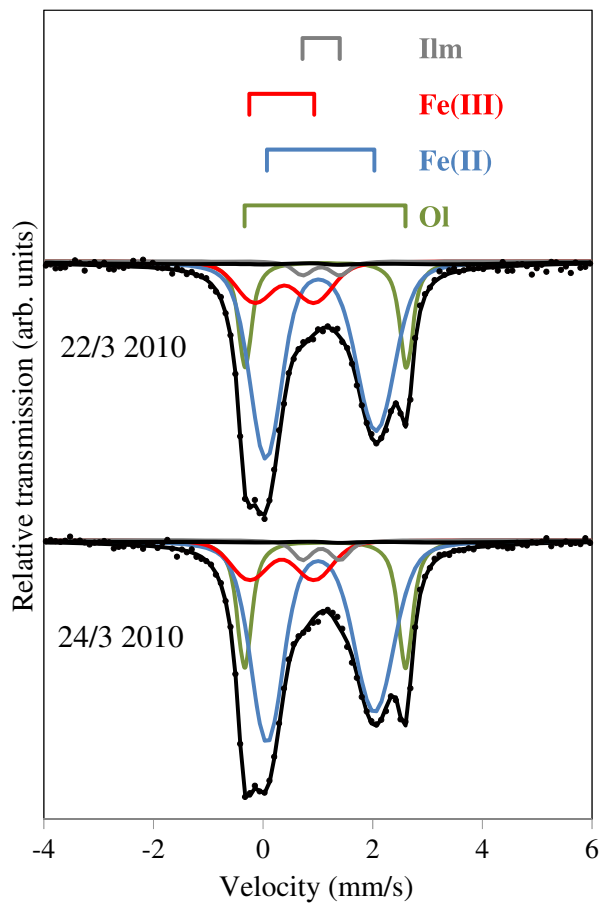

\section{Results}

\subsection{Samples from the Fimmvörðuháls eruption}

Figure 1 shows Mössbauer spectra of tephra samples from the Fimmvörðuháls eruption. The spectra were analysed in terms of five components, $\mathrm{Fe}(\mathrm{II})$ assigned to $\mathrm{Fe}^{2+}$ in glass, $\mathrm{Fe}$ (III) assigned to $\mathrm{Fe}^{3+}$ in glass, Ilm assigned to $\mathrm{Fe}^{2+}$ in ilmenite $\left(\mathrm{FeTiO}_{3}\right), \mathrm{Ol}$ assigned to $\mathrm{Fe}^{2+}$ in olivine $(\mathrm{Fe}, \mathrm{Mg})_{2} \mathrm{SiO}_{4}$ and a broad magnetic hyperfine field distribution assigned to iron-titanium oxide (not shown in Fig. 1). The presence of this last component is barely seen in the spectra, but evidenced from lower transmission in the wings $(-8$ to $-2 \mathrm{~mm} / \mathrm{s}$ and 5 to $8 \mathrm{~mm} / \mathrm{s})$ compared to the background $(<-9 \mathrm{~mm} / \mathrm{s}$ and $>9 \mathrm{~mm} / \mathrm{s})$. The signal is too small to firmly identify this component, but in view of the overall relatively reduced state of the samples, it was assumed to be titanomagnetite and was simulated with average parameters of titanomagnetite $\left(\mathrm{Fe}_{3-x} \mathrm{Ti}_{x} \mathrm{O}_{4}\right)$ with $x=0.6$ [6]. Doublet components were analysed with Voigt profiles, a convolution between a Lorentzian profile of full width at half maximum of $\Gamma$ and Gaussian profile with standard deviation of $\sigma$. For Fe(II) the two legs of the quadrupole doublet had the same area, but different Gaussian broadenings. The spectral fraction of ilmenite (Ilm) was too small to allow its hyperfine parameters to be included as fitting variables, and therefore table values from the literature were used [7]. Average hyperfine parameters and spectral areas are gathered in Table 2.

Overall, the hyperfine parameters obtained are in good agreement with their assignment. The parameters obtained for $\mathrm{Fe}(\mathrm{II})$ are in good agreement with 
Table 2 Hyperfine parameters and spectral areas obtained from the analysis of tephra samples from Fimmvörðuháls (Fig. 1)

\begin{tabular}{llllll}
\hline & Fe-Ox ${ }^{\mathrm{a}}$ & $\mathrm{Ol}$ & $\mathrm{Fe}(\mathrm{II})$ & $\mathrm{Fe}(\mathrm{III})$ & $\mathrm{Ilm}$ \\
\hline$B_{\mathrm{hf}}(\mathrm{T})$ & 25 & & & & \\
$\delta(\mathrm{mm} / \mathrm{s})$ & 0.77 & $1.14(1)$ & $1.05(5)$ & $0.36(3)$ & 1.06 \\
$\Delta E_{\mathrm{Q}}, 2 \varepsilon(\mathrm{mm} / \mathrm{s})$ & 0 & $2.94(1)$ & $1.98(9)$ & $1.14(4)$ & 0.68 \\
$\Gamma(\mathrm{mm} / \mathrm{s})$ & 0.45 & $0.27(2)$ & & & \\
$\sigma_{\mathrm{L}}(\mathrm{mm} / \mathrm{s})$ & & $0.0(1)$ & $0.23(1)$ & $0.28(2)$ & 0.1 \\
$\sigma_{\mathrm{R}}(\mathrm{mm} / \mathrm{s})$ & & & $0.30(1)$ & & \\
Area 22/3/2010 $(\%)$ & $5(2)$ & $16(2)$ & $61(3)$ & $14(1)$ & $3(1)$ \\
Area 24/3/2010 $(\%)$ & $4(1)$ & $20(2)$ & $59(3)$ & $13(1)$ & $4(1)$ \\
\hline
\end{tabular}

${ }^{a}$ Average hyperfine parameters of a distribution

The table lists the average magnetic hyperfine field $\left(B_{\mathrm{hf}}\right)$, isomer shift $(\delta)$, quadrupole splitting of doublets $\left(\Delta E_{\mathrm{Q}}\right)$ and quadrupole shift $(2 \varepsilon)$ for Fe-Ox, and line-width parameters. Numbers in parentheses represent the error in the last digit, values with omitted errors were fixed and not included as fitting variables

Fig. 2 Mössbauer spectra of a rock sample from Fimmvörðuháls. The upper spectrum marked "Rock" represents the whole-rock sample and the lower spectrum marked "M-Rock" is that of a magnetic separate of a crushed fraction of the whole-rock sample. The solid lines show the fitting components indicated with bar diagram on top and their sum (black line)

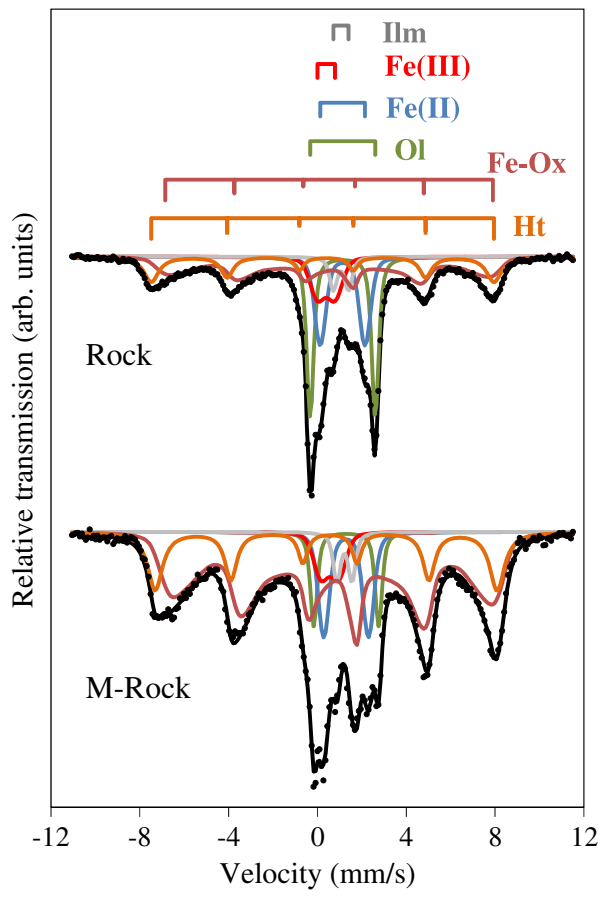

average parameters of $\mathrm{Fe}^{2+}$ in glass from [8], suggesting that crystallisation of pyroxene before quenching of the melt has been negligible. There is no significant difference in the spectral areas of components in the two samples. Using 20(2) \% higher $f$-factor of ferric $\mathrm{Fe}$ relative to ferrous $\mathrm{Fe}[9], \mathrm{Fe}^{3+} / \mathrm{Fe}_{\mathrm{Tot}}$ ratio of the melt (using only $\mathrm{Fe}(\mathrm{III})$ and $\mathrm{Fe}(\mathrm{II})$ ) is $15.6(6) \%$ and $11.9(5) \%$ for the whole rock.

A Mössbauer spectrum of a solidified rock sample from the Fimmvörðuháls eruption is presented in Fig. 2. 


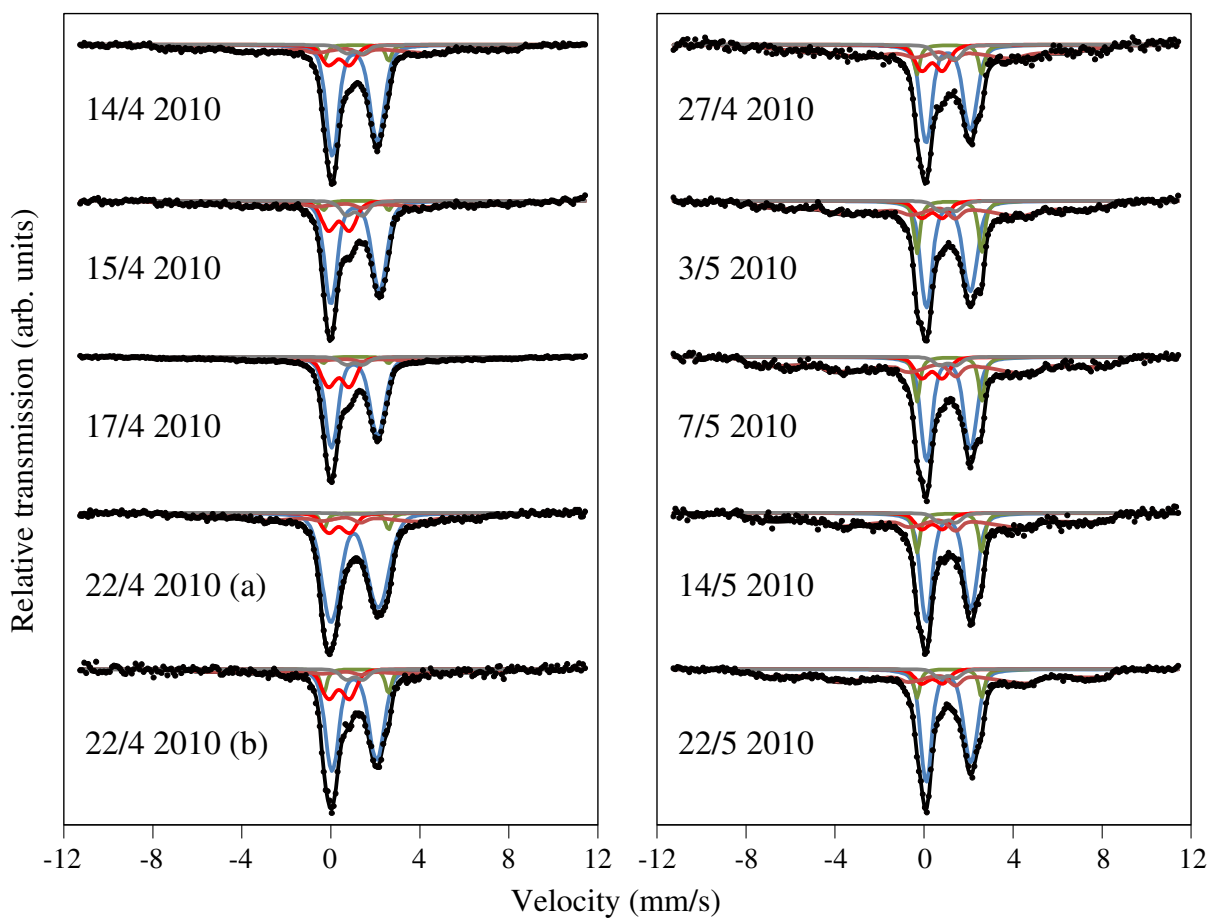

Fig. 3 Room-temperature Mössbauer spectra of samples from the Eyjafjallajökull eruption obtained at the dates indicated. Solid lines show the fitting components and their sum

The main difference between the rock sample and the tephra samples is the presence of magnetic sextets due to hematite $(\mathrm{Ht})$ and $\mathrm{Fe}-\mathrm{Ti}$ oxide $(\mathrm{Fe}-\mathrm{Ox})$ with parameters consistent with oxidized titanomagnetite. The area fraction of $\mathrm{Fe}^{3+}$ species in this sample is $\sim 41 \%$ compared with $\sim 15 \%$ of the tephra samples. This indicates that the magma oxidized when flowing over a wet (snowy) surface away from the crater. The rock sample would give a quite different oxidation state of the magma than the tephra samples, illustrating that care has to be taken upon interpretation of oxidation states.

\subsection{Time series of samples from the Eyjafjallajökull eruption}

Figure 3 shows Mössbauer spectra of samples acquired on different dates from the Eyjafjallajökull eruption. The spectra have been analysed in the same way as the spectra of the tephra samples from Fimmvörðuháls. The hyperfine parameters for Ol, $\mathrm{Fe}(\mathrm{III})$ and $\mathrm{Fe}-\mathrm{Ox}$ were taken as global variables, for Ilm, literature values were used. Only the hyperfine parameters of the dominant $\mathrm{Fe}(\mathrm{II})$ component were allowed to vary between measurements. Table 3 lists the global hyperfine parameters and Table 4 lists the hyperfine parameters of $\mathrm{Fe}(\mathrm{II})$.

The isomer-shift of $\mathrm{Ol}$ seems slightly low compared to usual isomer-shifts of Fe in olivine (usually $\delta=1.16(1) \mathrm{mm} / \mathrm{s}$ [7]). The reason for this apparent discrepancy is not known but a possibility is that this is due to trace foreign elements in the 
Table 3 Global hyperfine parameters used in the analysis of the spectra in Fig. 3

\begin{tabular}{lclll}
\hline & $\mathrm{Fe}-\mathrm{Ox}^{\mathrm{a}}$ & $\mathrm{Ol}$ & $\mathrm{Fe}(\mathrm{III})$ & $\mathrm{Ilm}$ \\
\hline$B_{\mathrm{hf}}(\mathrm{T})$ & $32(2)$ & & & \\
$\delta(\mathrm{mm} / \mathrm{s})$ & $0.53(5)$ & $1.135(3)$ & $0.38(2)$ & 1.06 \\
$\Delta E_{\mathrm{Q}}(\mathrm{mm} / \mathrm{s})$ & 0 & $2.892(6)$ & $0.97(3)$ & 0.68 \\
$\sigma(\mathrm{mm} / \mathrm{s})$ & & $0.055(6)$ & $0.251(5)$ & 0.1 \\
\hline
\end{tabular}

Values in parentheses represent the one sigma error in the last digit. Values with omitted errors were fixed and not included as fitting variables

${ }^{a}$ Average hyperfine parameters of a distribution

Table 4 Hyperfine parameters of Fe(II) obtained from the analysis of the spectra in Fig. 3

\begin{tabular}{lllll}
\hline Date 2010 & $\delta(\mathrm{mm} / \mathrm{s})$ & $\Delta E_{\mathrm{Q}}(\mathrm{mm} / \mathrm{s})$ & $\sigma_{\mathrm{L}}(\mathrm{mm} / \mathrm{s})$ & $\sigma_{\mathrm{R}}(\mathrm{mm} / \mathrm{s})$ \\
\hline $14 / 04$ & $1.079(3)$ & $2.001(7)$ & $0.205(5)$ & $0.259(6)$ \\
$15 / 04$ & $1.092(4)$ & $2.16(2)$ & $0.216(7)$ & $0.265(8)$ \\
$17 / 04$ & $1.071(4)$ & $2.045(7)$ & $0.222(5)$ & $0.275(4)$ \\
$22 / 04$ (a) & $1.077(4)$ & $2.13(2)$ & $0.352(6)$ & $0.428(8)$ \\
$22 / 04$ (b) & $1.059(6)$ & $1.99(3)$ & $0.24(2)$ & $0.28(2)$ \\
$27 / 04$ & $1.089(6)$ & $1.97(2)$ & $0.20(2)$ & $0.25(2)$ \\
$03 / 05$ & $1.094(4)$ & $1.94(2)$ & $0.184(8)$ & $0.247(9)$ \\
$07 / 05$ & $1.099(5)$ & $1.95(2)$ & $0.179(9)$ & $0.23(2)$ \\
$14 / 05$ & $1.101(5)$ & $1.99(2)$ & $0.19(2)$ & $0.24(2)$ \\
$22 / 05$ & $1.099(3)$ & $1.992(8)$ & $0.176(6)$ & $0.250(7)$ \\
\hline
\end{tabular}

structure (see supporting information of [4]). The average hyperfine parameters of Fe-Ox suggest oxidized titanomagnetite [6], and in $\mathrm{Fe}^{3+} / \mathrm{Fe}_{\text {Tot }}$ determinations it is assumed that $67 \pm 5 \%$ of the Fe-Ox component is due to ferric Fe.

The hyperfine parameters of $\mathrm{Fe}$ (II) show significant variation, which is difficult to relate to area fractions or eruption phases. They deviate in all cases from ideal glass parameters (see e.g. Table 2 or [9]) suggesting that the Fe(II) component is due to (at least) both $\mathrm{Fe}^{2+}$ in glass and (ortho/clino) pyroxenes in varying amounts. This means also that only whole-rock $\mathrm{Fe}^{3+} / \mathrm{Fe}_{\mathrm{Tot}}$ ratios are reliable as it is not possible to distinguish the melt/glass component with certainty from crystalline minerals.

The time-dependence of spectral area fractions are shown in Fig. 4. The most clear change during the eruption is in the spectral fractions of the materials erupted between 22/4 and 27/4 2010. This is seen as an increased fraction of Fe-Ox and Ol, and a reduced fraction of $\mathrm{Fe}(\mathrm{II})$.

All samples from the Eyjafjallajökull eruption show the presence of $\mathrm{Fe}^{2+}$ in olivine. This can be regarded as a surprise; taking the average whole-rock analysis [3] with the $\mathrm{Fe}^{3+} / \mathrm{Fe}_{\mathrm{Tot}}$ ratios found here; neither CIPW norm [10] nor MELTS calculations $[11,12]$ suggest that olivine should be found. This result is, however, in agreement with the observations of $[3,4]$ that the two components that make up the melts from Eyjafjallajökull eruption, did not fully mix to form a homogeneous melt. In that case, the olivine is a part of the mafic component.

The $\mathrm{Fe}^{3+} / \mathrm{Fe}_{\mathrm{Tot}}$ ratio, evaluated under the assumption that the $f$-factor of ferric $\mathrm{Fe}$ is 20(2) \% higher than that of ferrous Fe is shown in Fig. 5. The ratio shows significant variations, from $21.5(16) \%$ for the $22 / 4$ (a) sample to $33.8(26) \%$ for the $27 / 4$ sample. An accurate determination of $\mathrm{Fe}^{3+} / \mathrm{Fe}_{\mathrm{Tot}}$ ratio is somewhat hampered by the relatively large error assigned to the ferric proportion of the Fe-Ox component, although the spectral fractions are determined more accurately. The Mössbauer 
Fig. 4 Area fraction of the fitting components used for the analysis of the spectra in Fig. 3. The bar diagram at the top refers to the eruption phases outlined in Table 1.

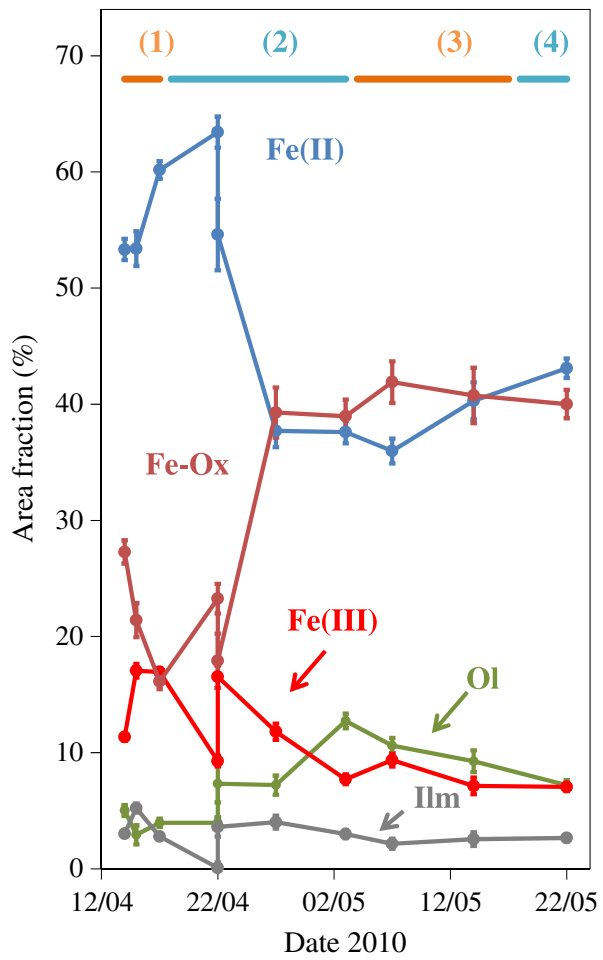

Fig. $5 \mathrm{Fe}^{3+} / \mathrm{Fe}_{\mathrm{Tot}}$ ratio obtained from Mössbauer measurements of a time series of samples from the Eyjafjallajökull eruption

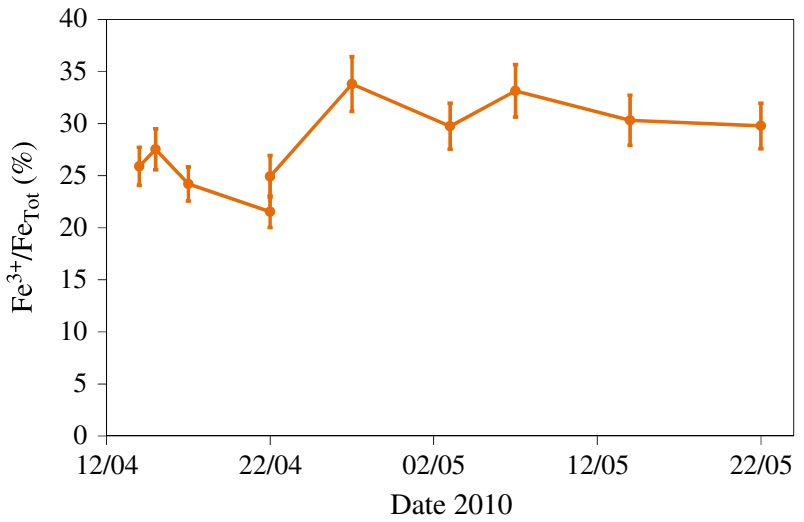

spectrum of the most reduced sample 22/4 (a) is very distinctive from the others as seen for example in the line-width of the $\mathrm{Fe}(\mathrm{II})$ component (Table 4). To study this sample in greater detail, a major element analysis was performed.

Table 5 lists new whole-rock analyses of the 17/4 and 22/4 (a) samples compared with analyses available in the literature for Fimmvörðuháls samples and glass from tephra from the 1821-1823 AD Eyjafjallajökull eruption.

The analysis of the 17/4 sample is in rough agreement with average analyses from from the work of Sigmarsson et al. [3] of samples from the Eyjafjallajökull eruption. 
Table 5 Major element analysis of samples from the Fimmvörðuháls/Eyjafjallajökull eruption

\begin{tabular}{lcccc}
\hline & $\mathrm{FVH}$ & $22 / 4(\mathrm{a})$ & $17 / 4$ & $1821-3$ \\
\hline $\mathrm{SiO}_{2}$ & $46.3(4)$ & 56.35 & $57.2(6)$ & 69.13 \\
$\mathrm{TiO}_{2}$ & $2.9(2)$ & 1.75 & $1.72(8)$ & 0.36 \\
$\mathrm{Al}_{2} \mathrm{O}_{3}$ & $15.0(2)$ & 14.99 & $14.8(2)$ & 14.1 \\
$\mathrm{FeO}$ & $10.6(4)^{\mathrm{a}}$ & $8.57^{\mathrm{a}}$ & $7.0(3)^{\mathrm{a}}$ & $4.29^{\mathrm{b}}$ \\
$\mathrm{Fe}_{2} \mathrm{O}_{3}$ & $1.60(9)^{\mathrm{a}}$ & $2.16^{\mathrm{a}}$ & $2.7(2)^{\mathrm{a}}$ & \\
$\mathrm{MnO}$ & $0.182(6)$ & 0.25 & $0.24(1)$ & 0.15 \\
$\mathrm{MgO}$ & $8.6(4)$ & 4.86 & $2.6(3)$ & 0.13 \\
$\mathrm{CaO}$ & $10.0(2)$ & 6.16 & $5.4(3)$ & 1.1 \\
$\mathrm{Na}_{2} \mathrm{O}$ & $2.9(2)$ & 4.57 & $5.15(7)$ & 6.14 \\
$\mathrm{~K}_{2} \mathrm{O}$ & $0.61(5)$ & 1.68 & $1.9(1)$ & 3.5 \\
$\mathrm{P}_{2} \mathrm{O}$ & $0.41(2)$ & 0.34 & $0.38(2)$ & 98.91 \\
$\mathrm{Sum}$ & 99.2 & 101.33 & 99.02 & \\
\hline
\end{tabular}

FVH = Fimmvörðuháls-data from [3], numbers in parentheses represent the standard deviation of 4 samples; $17 / 4=$ average of 6 measurements, numbers in parentheses represent the standard deviation; 1821-3 = data from [5] on glass chemistry of Eyjafjallajökull 1821-1823 tephra ${ }^{\mathrm{a}} \mathrm{FeO}$ and $\mathrm{Fe}_{2} \mathrm{O}_{3}$ calculated from $\mathrm{Fe}^{3+} / \mathrm{Fe}_{\mathrm{Tot}}$ ratios determined here

${ }^{\mathrm{b}}$ Total iron expressed as $\mathrm{FeO}$

The chemistry of the 22/4 (a) sample is different, and specifically the differences in $\mathrm{MgO}$ and $\mathrm{CaO}$ content are of interest in view of the mixing model of Sigmarsson et al., (Fig. $3 \mathrm{a}$ in [3]). The $\mathrm{CaO}$ and $\mathrm{MgO}$ content suggests a larger amount of the mafic component compared to other samples from the eruption. It is therefore concluded that at least part of the variation presented in Fig. 5 is due to different mixing of the two end-members making up the eruptive materials from the Eyjafjallajökull eruption.

However, before firm conclusions on the $\mathrm{Fe}^{3+} / \mathrm{Fe}_{\mathrm{Tot}}$ ratio can be reached, alternative explanations of the high oxidation state have to be explored. It was evident from the analysis of the rock samples from Fimmvörouháls (Fig. 2) that the amount of ferric Fe can be due to secondary oxidation, and similar effects could be invoked here as an explanation of the high $\mathrm{Fe}^{3+} / \mathrm{Fe}_{\mathrm{Tot}}$ ratios.

The obvious candidate explanation for raising the oxidation state is the interaction of the magma with water from the ice covered volcano. In order to address this in some detail, size-separated samples and a lava bomb were investigated.

\subsection{Size-separated samples}

There is evidence from scanning electron microscopy studies [13] that the fragmentation process in the beginning of the Eyjafjallajökull eruption was due to watermagma interaction. It would therefore be a logical interpretation that the more fragmented part of a sample (the smaller particles) had been more affected by interactions with water than the larger particles. In that case, one could expect to see a size dependence of the $\mathrm{Fe}^{3+} / \mathrm{Fe}_{\mathrm{Tot}}$ ratio, where the largest particles would best preserve the original $\mathrm{Fe}^{3+} / \mathrm{Fe}_{\text {Tot }}$ ratio of the magma.

The sample from 17/4 2010 was separated using sieves. The sample $<38 \mu \mathrm{m}$ was further separated using sedimentation and Stokes law (see [14] for details on the method). Mössbauer spectra (not shown) were used to determine $\mathrm{Fe}^{3+} / \mathrm{Fe}_{\mathrm{Tot}}$ ratios shown in Fig. 6. 
Fig. $6 \mathrm{Fe}^{3+} / \mathrm{Fe}_{\mathrm{Tot}}$ ratio determined from Mössbauer spectra of different size fractions. The inset picture shows the distribution of masses in the size bins from sieving

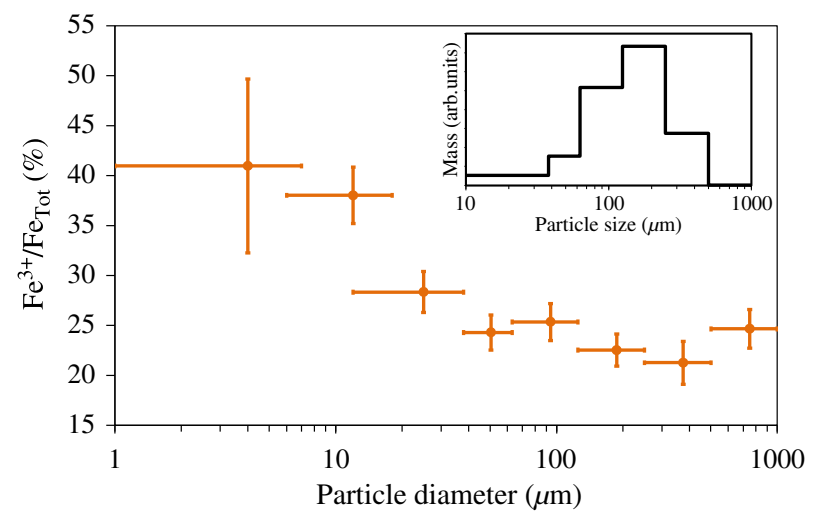

Fig. 7 Picture of a slice of the lava bomb. The original sample was close to spherical and $\sim 20 \mathrm{~cm}$ in diameter. The surface appeared glassy, evidencing quenching. The numbers show subdivisions of samples

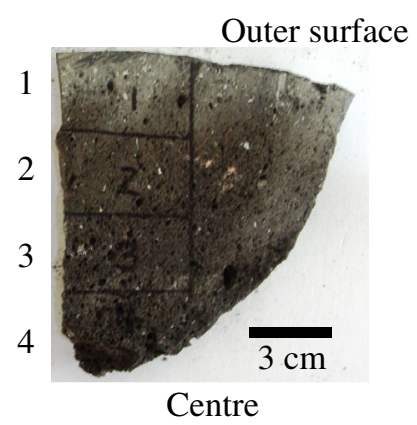

Only the sieved samples $<38 \mu \mathrm{m}$ showed slightly elevated $\mathrm{Fe}^{3+} / \mathrm{Fe}_{\mathrm{Tot}}$ ratio of $29.4(20) \%$. However, this size fraction is less than $1 \%$ of the weight of the whole sample, and has negligible effect on the $\mathrm{Fe}^{3+} / \mathrm{Fe}_{\mathrm{Tot}}$ ratio determined on the whole sample. From this, it can be concluded that the oxidation due to water/magma interactions has been short and that the $\mathrm{Fe}^{3+} / \mathrm{Fe}_{\text {Tot }}$ ratios determined in Fig. 5 are not affected by higher oxidation state of the finer particles.

\subsection{Lava bomb samples}

It can still be argued that the samples were affected as a whole by the interaction with water. To investigate that, a lava bomb was investigated. Lava bombs are clumps of lava, ejected during an eruption in a liquid or at least plastic state, which often takes on a near spherical shape in flight. Only the surface can be subjected to major interactions with water and/or atmosphere, and the interior can be regarded as representative of the melt.

A lava bomb was collected shortly after the eruption, and probably originates from late in the eruption (Á. Höskuldsson 2011, private communication). The original rock was $\sim 20 \mathrm{~cm}$ in diameter (see Fig. 7) and had a glassy surface. Slower cooling of the interior was evidenced by more evolved gas bubbles in the centre of the bomb.

A slice of the bomb was subdivided into 4 samples depending on the distance from the surface, as indicated in Fig. 7. 
Fig. 8 Room-temperature Mössbauer spectra of the lava bomb sample
Table 6 Area fractions obtained from the analysis of the spectra in Fig. 8

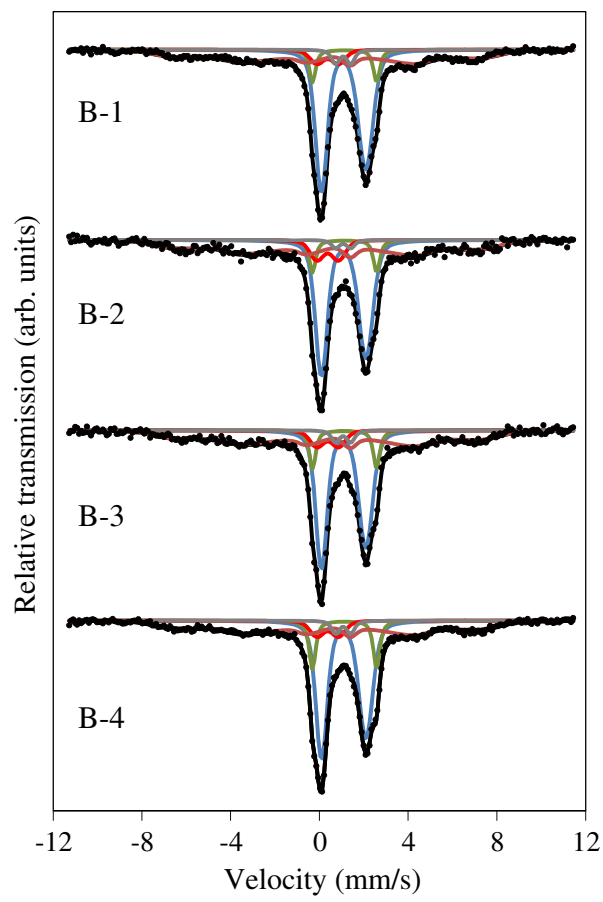

\begin{tabular}{llrlll}
\hline Sample & $\mathrm{Fe}(\mathrm{II})$ & $\mathrm{Ol}$ & $\mathrm{Fe}(\mathrm{III})$ & $\mathrm{FeOx}$ & $\mathrm{Ilm}$ \\
\hline 1 & $49.0(9)$ & $7.0(5)$ & $5.5(3)$ & $35(1)$ & $3.5(3)$ \\
2 & $45(2)$ & $6.8(9)$ & $7.7(6)$ & $37(2)$ & $2.0(5)$ \\
3 & $44(2)$ & $8.1(6)$ & $6.3(5)$ & $38(2)$ & $2.9(4)$ \\
4 & $45.1(9)$ & $10.2(6)$ & $6.1(4)$ & $35(2)$ & $3.1(3)$ \\
\hline
\end{tabular}

The Mössbauer spectra (Fig. 8) of different samples show only minor differences. The parameters are identical to those obtained for the time series (Tables 3 and 4) and spectral areas are given in Table 6.

The area fractions are approximately consistent with the area fractions of components observed in the last phase of the eruption. The most obvious trend in the dataset is the decrease of the $\mathrm{Fe}(\mathrm{II}) / \mathrm{Ol}$ ratio toward the centre of the bomb. The $\mathrm{Fe}^{3+} / \mathrm{Fe}_{\text {Tot }}$ ratio of $27(2) \%$ is also in reasonable agreement with the data in Fig. 5, and shows no increase toward the surface of the sample.

The important finding from the lava bomb is that interactions with water/atmosphere have not altered the ferric ratio significantly, allowing us to conclude that the whole-rock ferric ratios displayed in Fig. 5 are reliable.

\subsection{Sample from the 1821-1823 eruption}

According to $[3,4]$, the material that erupted in the Eyjafjallajökull eruption appears to be a mixture of two components, one akin the Fimmvörouháls magma, the other that of the 1821-1823 Eyjafjallajökull eruption. 
Fig. 9 Mössbauer spectrum of a tephra sample from the 1821-1823 Eyjafjallajökull eruption

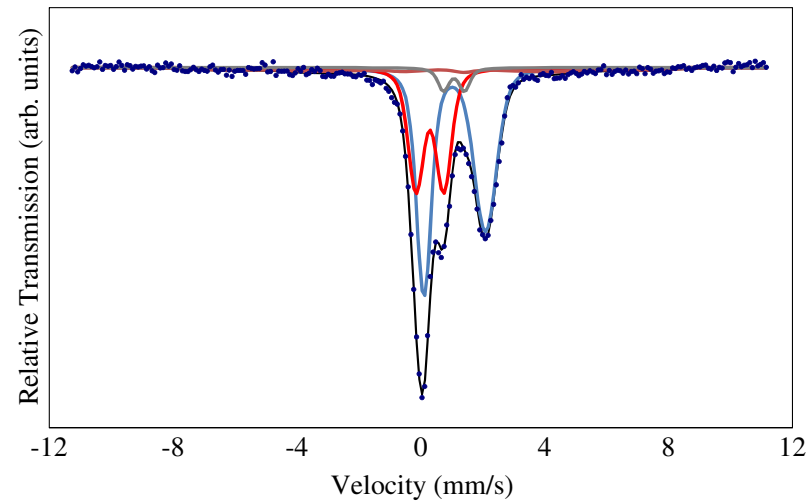

The Mössbauer spectrum of a tephra sample from the 1821-1823 (Fig. 9) can be analysed in terms of the same components as before except that $\mathrm{Ol}$ is not present in this sample. The $\mathrm{Fe}^{3+} / \mathrm{Fe}_{\text {Tot }}$ ratio is found to be 32.4(20) \% using the same methods as above.

It should be emphasized that the $\mathrm{Fe}^{3+} / \mathrm{Fe}_{\text {Tot }}$ ratio of samples from the Eyjafjallajökull (Fig. 5) are not a simple sum of the mixing proportions of Fimmvörðuhálslike material and 1821-1823 AD Eyjafjallajökull-like material. Both mixing endmembers show evolution [3] that would have to be taken into account.

\section{Discussion}

The striking variation with time observed in the Mössbauer analysis of samples from the Eyjafjallajökull eruption is the abrupt change in the relative ratios of $\mathrm{Fe}(\mathrm{II})$ and Fe-Ox (Fig. 4). This seems not to be correlated with eruption phases in Table 1, and suggests a change in the eruption between 22/4 and 27/4 2010.

The relative increase in the Fe-Ox component, suggests more crystallization in the latter part of the eruption. Some of the Fe in the melt (part of Fe(II) and Fe(III)) combines to form inverse spinel-type iron oxides (Fe-Ox). This would suggest either lower quenching temperature and/or lower quenching rate of the melt in the latter part of the eruption. As water (glacier melt) is probably the factor that mainly controls the quenching of the melt, these changes suggest less access of water to the melt.

This is in accordance with the scanning electron microscopy observation of Dellino et al. [13] that reveals that ash produced during the first phase of the eruption shows key features of magma-water interaction while fragmentation was purely magmatic in the last phase of the eruption.

\section{Conclusions}

Mössbauer spectroscopy has been used to determine $\mathrm{Fe}^{3+} / \mathrm{Fe}_{\mathrm{Tot}}$ ratios in samples from the Fimmvörðuháls/Eyjafjallajökull eruptions. For the Fimmvörðuháls sam- 
ples, a whole-rock $\mathrm{Fe}^{3+} / \mathrm{Fe}_{\mathrm{Tot}}$ ratio of $11.9(5) \%$ is determined whereas $\mathrm{Fe}^{3+} / \mathrm{Fe}_{\mathrm{Tot}}$ ratio of the glass is found to be $15.6(6) \%$.

Samples from the Eyjafjallajökull eruption contain $\mathrm{Fe}^{2+}$ in olivine which is consistent with mingling and mixing of two components, a mafic component (with olivine) and silicic magma as found from studies of the chemical composition of samples [3, 4]. Samples from the Eyjafjallajökull eruption have $\mathrm{Fe}^{3+} / \mathrm{Fe}_{\mathrm{Tot}}$ ratios ranging from $21.5(16) \%$ to $33.8(26) \%$. At least part of this variation is explained by different mixing proportions of the end-members.

Mössbauer spectra of samples taken during the eruption suggest higher degree of crystallization in the latter part of the eruption, either due to lower quenching temperature of the magma and/or lower quenching rate, in both cases evidencing that access to water was reduced in the latter part of the eruption.

Acknowledgements We wish to express our gratitude to the Villum Kann Rasmussen Foundation for support of field work, and our thanks are due to Elly Hein for XRF analyses, and Birthe Eriksen and Bente Rasmussen for sample preparation and particle size analyses by laser diffraction.

\section{References}

1. The Eyjafjallajokull Volcanic Eruption in 2010. J. Geophys. Res. 117 (2012). http://onlinelibrary. wiley.com/journal/10.1002/(ISSN)2169-9356/specialsection/ICEVOLCAN1

2. Moune, S., Sigmarsson, O., Schiano, P., Thordarson, T., Keiding, J.K.: Melt inclusion constraints on the magma source of Eyjafjallajökull 2010 flank eruption. J. Geophys. Res. 117, B00C07 (2012)

3. Sigmarsson, O., Vlastelic, I., Andreasen, R., Bindeman, I., Devidal, J.-L., Moune, S., Keiding, J.K., Larsen, G., Höskuldsson, A., Thordarson, Th.: Remobilization of silicic intrusion by mafic magmas during the 2010 Eyjafjallajökull eruption. Solid Earth 2, 271-281 (2011)

4. Keiding, J.K., Sigmarsson, O.: Geothermobarometry of the 2010 Eyjafjallajökull eruption: new constraints on Icelandic magma plumbing systems. J. Geophys. Res. 117, B00C09 (2012)

5. Larsen, G., Dugmore, A., Newton, A.: Geochemistry of historical-age silicic tephras in Iceland. The Holocene 9, 463-471 (1999)

6. Gunnlaugsson, H. P., Rasmussen, H., Kristjánsson, L., Steinthorsson, S., Helgason, Ö., Nørnberg, P., Madsen, M.B., Mørup, S.: Mössbauer spectroscopy of magnetic minerals in basalt on Earth and Mars. Hyperfine Interact. 182, 87-101 (2008)

7. Stevens, J.G. (Ed.).: Mössbauer Mineral Handbook. Mössbauer Effect Data Center (1998)

8. Helgason, Ö., Steinthorsson, S., Mørup, S., The ferric/ferrous ratio in basalt melts at different oxygen pressures. Hyperfine Interact. 45, 287-294 (1989)

9. De Grave, E., Van Alboom, A.: Evaluation of ferrous and ferric Mössbauer fractions. Phys. Chem. Miner. 18, 337-342 (1991)

10. Verma, S.P., Torres-Alvarado, I.S., Velasco-Tapia, F.: Schweiz. Mineral. Petrogr. 83, 197-216 (2003)

11. Ghiorso, M.S., Sack, R.O.: Chemical mass transfer in magmatic processes. IV. A revised and internally consistent thermodynamic model for the interpolation and extrapolation of liquidsolid equilibria in magmatic systems at elevated temperatures and pressures. Contrib. Mineral. Petrol. 119, 197-212 (1995)

12. Asimow P.D., Ghiorso M.S.: Algorithmic modifications extending MELTS to calculate subsolidus phase relations. Am. Mineral. 83, 1127-1131 (1998)

13. Dellino, P., Gudmundsson, M.T., Larsen, G., Mele, D., Stevenson, J.A., Thordarson, T., Zimanowski, B.: Ash from the Eyjafjallajökull eruption (Iceland): fragmentation processes and aerodynamic behaviour. J. Geophys. Res. 117, B00C04 (2012)

14. Mølholt, T.E., Gunnlaugsson, H.P., Merrison, J.P., Morris, R.V., Nørnberg, P.: Mössbauer and VNIR study of dust generated from olivine basalt: application to Mars. Hyperfine Interact. 186, 127-133 (2008) 